Acta Technologica Agriculturae 1

Nitra, Slovaca Universitas Agriculturae Nitriae, 2015, pp. 18-21

\title{
EVALUATING THE EFFECTIVENESS OF PRODUCTION PROCESS USING PARETO ANALYSIS
}

\author{
Pavel POLÁK*, Miroslav PRÍSTAVKA, Katarína KOLLÁROVÁ
}

Slovak University of Agriculture in Nitra, Slovak Republic

\begin{abstract}
The aim of this paper is to present the possibilities of using the Pareto method in evaluating the effectiveness of machine production processes. The paper deals with the production process of material cutting using progressive technology and subsequent evaluation of its effectiveness and quality. In the production process, we have used the method of material cutting by abrasive water jet. The Pareto analysis was used for eliminating the shortcomings in the quality of the final part.
\end{abstract}

Keywords: abrasive water jet, statistical method, manufacturing process

Any material may be characterised according to certain properties. These properties determine the suitability of material for a particular application. Knowing and improving the mechanical properties of metallic structural materials is socially motivated by their optimal use in the manufacture of machinery and equipment. Production processes are being intensified in all manufacturing sectors, the speed of transport is increasing, operating parameters of energy facilities are rising, and new, qualitatively different demands on material properties are originating. These ever-increasing demands on new and improved properties of metallic materials must be complied with guaranteed safety, reliability and lifetime of manufactured machines and structures. Nowadays, material can be machined using new, unconventional techniques by means of electrochemical reaction, plasma, laser, liquid and other physical factors. Due to the possibility of introducing full automation and mechanisation, and due to the possibility of producing complex shapes and high precision in manufacturing, these methods are most frequently used in industrial production. The technology of abrasive water jet machining is used mainly for material cutting, cutting of shapes, and other machining technologies.

\section{Material and methods}

\section{Hydro-abrasive material cutting}

Material cutting by water jet or hydro-abrasive cutting is defined as a computer-controlled high-erosive process. The principle of hydro-abrasive cutting is in forcing the hydroabrasive stream or only the water at supersonic speed to the cut material, which causes its disintegration. The greatest advantage of this technology comparing to other cutting methods is a cold cutting process. A dividing head (Figure 1) ensures an optimum dividing performance, the highest dividing speed at the lowest operating costs. The dividing head enables cutting all materials with pure water, or water jet with added abrasive while reaching a high quality of cut surfaces.

This technology is used where the non-cutting, cutting and thermal processing techniques provide unsatisfactory results for mechanical or physical reasons, or where they completely fail (Fabianová, 2007). In contrast to thermal (heat) methods, it is possible to cut all materials (using water jet), without being influenced by heat. This eliminates their quenching, there is no warping of material, no dross is created, no molten material, and also no harmful substances such as toxic gases are formed. These toxic gases are often formed in plasma cutting of plastic materials; therefore, they should be disposed of. As for metal sheets coated with a plastic layer, this cutting technique is often the only solution that does not adversely affect the surface layer

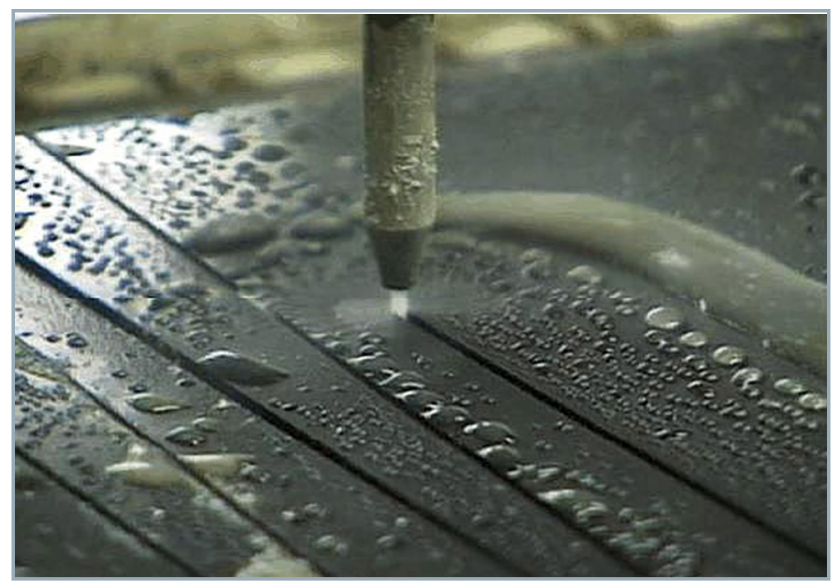

Figure 1 Water jet cutting of materials

Contact address: *Pavel Polák, Slovak University of Agriculture in Nitra, Faculty of Engineering, Department of Quality and Engineering Technologies, Tr. Andreja Hlinku 2, 94976 Nitra, Slovak Republic, e-mail: pavel.polak@uniag.sk 


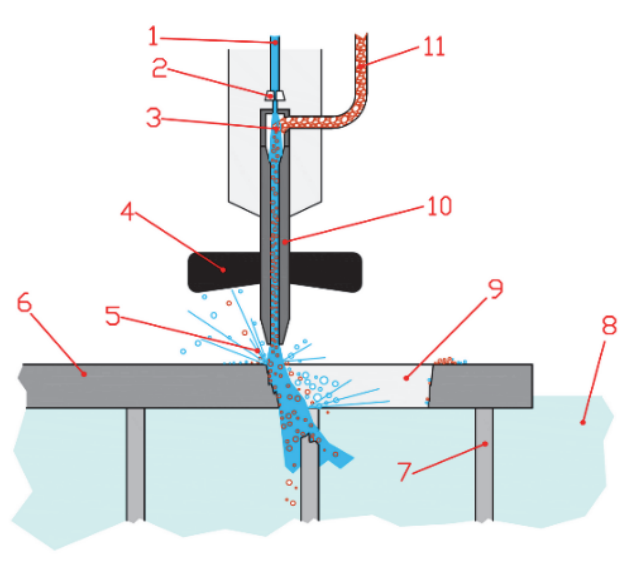

Figure 2 Scheme of machining by abrasive water jet 1 - supply of high pressure water, 2 - water nozzle, 3 mixing chamber, 4 - protective cover, 5 - splashing water, 6 - workpiece, 7 - grating, 8 - water in a collecting vessel, 9 - cut hole in the workpiece, 10 - abrasive - mixing nozzle, 11 - abrasive - garnet, peridot, silica sand

(Hloch and Valíček, 2009). Abrasive water jet is achieved when the pure water jet is mixed with abrasive in the dividing head (in a mixing chamber), thereby achieving a suspension of water and abrasive, which focuses (concentrating the non-parallel beam of abrasive parts) in the abrasive nozzle and leaves it as hydro-abrasive cutting water jet. That causes micro-cutting operation by abrasion cutting of the material with a thin water jet (Figure 2).

\section{Evaluation of cut quality by Pareto method}

The Pareto method assumes that:

- Only $20 \%$ of the causes are associated with up to $80 \%$ of the losses; therefore, it is necessary to pay high attention to these $20 \%$ of vital causes, which will resolve $80 \%$ of the losses (task for optimisation - minimisation of losses from poor quality production).

- The core of the product requires up to $80 \%$ of production costs, but has only a $20 \%$ impact on the customer. On the contrary, surroundings, advertising, and brand - an intangible part represents only $20 \%$ of production costs, but has up to an $80 \%$ impact on the consumer (task to optimise the cost of production and non-production activities).

- From the total production, $20 \%$ of company's products bring the company $80 \%$ of profits (task for deciding on the optimum portfolio of products composition at present, but with a reserve - a risk into the future).

The Pareto principle allows an insight into the most diverse phenomena, distinguishing important phenomena from those less essential, identifying the main problems and their causes, and thus determining the direction for corrective actions (Mateides, 2006). This makes it a logical and meaningful decision-making tool. Those key factors are called 'vital' to deal with the problem, other factors are 'insignificant' and it is generally not needed to deal with them in a given phase of solution.

Of course, it is possible that after mastering the vital problems of the first phase of solution, initially insignificant problems in this phase become vital in the second phase. The dynamics of this approach lies in the fact that the importance of problems may change with time, and is actually changing.

\section{Results and discussion}

\section{Analysis of determining the vital minority of factors using $80 / 20$ criterion}

The Pareto analysis was selected as a method for evaluation and comparison of cut quality on the monitored type of device. During the monitored period of time, there were recorded shortcomings in the production process that significantly affected the quality of the final product (Nenadál, 2001).

The aim was to exclude or reduce the number of the most frequent failures greatly affecting the quality in the production process. The analysis was conducted using the Pareto chart, which is a combination of the histogram of ordinal variables sorted according to the frequency of individual variants and the Lorenz curve.

The number of individual types of failures that have been identified by observation and evaluated as well as their absolute frequency is recorded in Table 1.

Table 1 Frequency of occurrence of individual types of failures

\begin{tabular}{|l||c|c|}
\hline Type & Designation & $\begin{array}{c}\text { Absolute } \\
\text { frequency }\end{array}$ \\
\hline \hline Failure of pressure regulator & $\mathrm{A}$ & 45 \\
\hline Cut error & $\mathrm{B}$ & 68 \\
\hline Shape deformation & $\mathrm{C}$ & 32 \\
\hline Abrasion of burner & $\mathrm{D}$ & 23 \\
\hline Handling error & $\mathrm{E}$ & 12 \\
\hline Power outage & $\mathrm{F}$ & 11 \\
\hline Other failure & $\mathrm{G}$ & 8 \\
\hline In total & 199 & \\
\hline
\end{tabular}

Consequently, it was necessary to organise the individual types of failures according to their absolute frequencies from the most to the least represented (Table 2).

Table 2 Organisation according to absolute frequencies of failures

\begin{tabular}{|l||c|c|}
\hline Type & Designation & $\begin{array}{c}\text { Absolute } \\
\text { frequency }\end{array}$ \\
\hline \hline Cut error & $\mathrm{B}$ & 68 \\
\hline Failure of pressure regulator & $\mathrm{A}$ & 45 \\
\hline Shape deformation & $\mathrm{C}$ & 32 \\
\hline Abrasion of burner & $\mathrm{D}$ & 23 \\
\hline Handling error & $\mathrm{E}$ & 12 \\
\hline Power outage & $\mathrm{F}$ & 11 \\
\hline Other failure & $\mathrm{G}$ & 8 \\
\hline In total & 199 & \\
\hline
\end{tabular}


Table 3

Values of relative and cumulative failure frequencies

\begin{tabular}{|l|c|c|c|}
\hline \multicolumn{4}{|c|}{ Organised table of frequencies } \\
\hline Failure type & Number of failures & Relative frequency & Cumulative relative frequency \\
\hline B & 68 & 0.3417 & 0.3417 \\
\hline A & 45 & 0.2261 & 0.5678 \\
\hline C & 32 & 0.1608 & 0.7286 \\
\hline D & 23 & 0.1156 & 0.8442 \\
\hline E & 12 & 0.0603 & 0.9045 \\
\hline F & 11 & 0.0553 & 0.9598 \\
\hline G & 8 & 0.0402 & 1.00 \\
\hline In total & 199 & 1.00 & \\
\hline
\end{tabular}

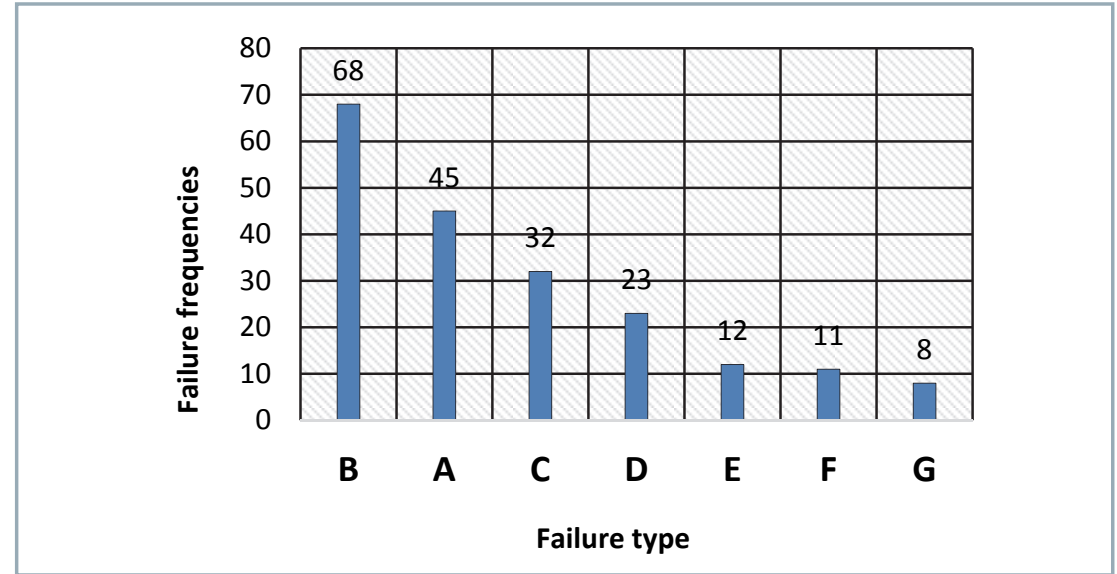

Figure 3 Histogram of failure frequencies

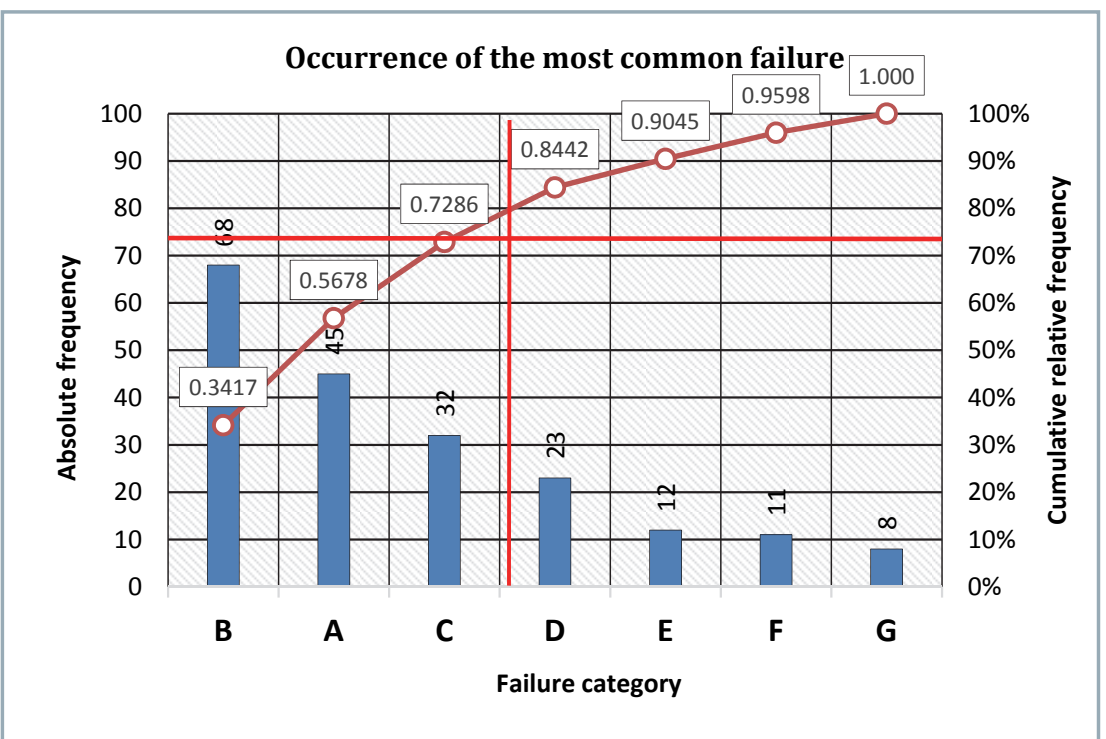

Figure 4 Pareto chart with Lorenz curve

The obtained values of organised absolute failure frequencies were used to create a histogram of absolute frequencies (Figure 3).

In the next step, it was necessary to calculate the relative frequencies of individual types of failures and then

to calculate the cumulative relative frequencies needed to construct the Lorenz curve. All the calculated values are reported in Table 3.

Subsequently, the Lorenz curve (calculated according to cumulative relative frequencies) was plotted in the histogram of absolute frequencies (Figure 4).

\section{Determining the limit of vital minorities of factors}

The evaluation of Pareto analysis using the criterion of average value of the selected indicator. The average number of failures $P$ per one type of failure was calculated according to Eq. (1) from the values (Table 2):

$$
\begin{gathered}
P=\frac{\sum \text { failures }}{\text { Nr.of failure types }}= \\
=\frac{199}{7}=28.43
\end{gathered}
$$

Subsequently, the values were compared (Table 2, column 3) with the average calculated value of the number of failures $\mathrm{P}$ (Table 4).

Table 4 Comparing the number of failures with $P$

\begin{tabular}{|l||c|c|}
\hline Serial no & Failure & Comparison \\
\hline \hline $\mathbf{1}$ & B & $68>28.43$ \\
\hline $\mathbf{2}$ & A & $45>28.43$ \\
\hline $\mathbf{3}$ & C & $32>28.43$ \\
\hline $\mathbf{4}$ & D & $23<28.43$ \\
\hline $\mathbf{5}$ & E & $12<28.43$ \\
\hline $\mathbf{6}$ & F & $11<28.43$ \\
\hline $\mathbf{7}$ & G & $8<28.43$ \\
\hline
\end{tabular}

\section{Conclusion}

The basic criterion for determining the vital minority of factors is the $80 / 20$ criterion, the Pareto principle. The criterion is applied so that we subtract $80 \%$ from the right $y$-axis and plot them through the Lorenz curve to the $x$-axis (Figure 4). The factors lying to the 
left of the vertical line directing from the Lorenz curve to the $\mathrm{x}$-axis form the sought vital minority of factors. The course of the Lorenz curve itself also may indicate where the line between the vital minority of factors and the useful majority results - the borders lead through the point representing a significant turning point in the behaviour of this curve.

In this case, the limit of the vital minority was obtained based on gradually comparing the value of the selected indicator in individual factors with the average value of this indicator. The factor in which the value of the given indicator is lower than the average no longer belongs to the vital minority and thus is not included in the deeper analysis as well as all the factors following it (Table 2, Eq. 1).

According to the analysis using the $80 / 20$ criterion, it can be concluded that the cut error factor has the largest share in quality, i.e. $34 \%$ (rounded off). The organisation should also focus on removing the shortcomings identified under the $A$ and $C$ indices. Specifically, it is the failure of the pressure regulator and shape deformation, in which remedy would lead to a significant quality improvement of the monitored production process. Similarly, according to the determined vital minority of factors, the frequency of occurrence in the fourth type of failure is lower than the average value. This means that the line of vital minority was determined between the factors identified as $C$ and $D$, which was confirmed by the analysis using the $80 / 20$ criterion, too. The final step of the Pareto analysis is the analysis of the factors identified as vital minority with the aim to take corrective measures leading to reducing the impact of these factors and to improving the process. The Pareto chart can then be re-used to evaluate the effectiveness of measures taken. When using the Pareto chart to reflect the condition before taking measures and the condition after implementation, the effect of measures should be perceptible from the comparison of the two charts.
High attention to the $80 / 20$ principle was paid by an English economic consultant of a world-famous company Boston Consulting Group and a partner of Bain \& CompanyRichard Koch. According to Koch (2000), $20 \%$ of inputs bring the company $80 \%$ of outputs, $20 \%$ of company's employees bring $80 \%$ of its productivity, $20 \%$ of products bring $80 \%$ of profits, and $20 \%$ of activities bring $80 \%$ of success. The remaining $80 \%$ is much less important in terms of outputs, and they are ideally to be eliminated after being examined, or to be completely disposed off.

\section{Acknowledgements}

This paper was prepared with a financial support of the grant project KEGA no. 035SPU-4/2014 'Integrating innovative trends in metal machining, metrology and quality management in university studies'.

\section{References}

FABIANOVÁ, J. 2007. Význam skúmania vplyvu rezných parametrov pri rezaní vodným lúčom. In Výrobné inžinierstvo, roč. 6, 2007, č. 2, s. 53-55.

HLOCH, S. - VALíČEK, J. 2009. Drsnost' povrchu a hydroabrazívne delenie. In Strojárstvo: mesačník o strojárstve, roč. 13, 2009, č. 11, s. $86-87$.

$\mathrm{KOCH}$, R. 2000. Pravidlo 80/20. Umenie dosiahnut čo najlepších výsledkov s čo najmenším úsilím. Praha : Management Press, 2000. ISBN 80-7261-008-2.

MATEIDES, A. 2006. Manažérstvo kvality. História, koncepty, metódy. Bratislava : Ing. Miroslav Mračko - Epos, 2006. ISBN 80-8057-656-4. NENADÁL, J. 2001. Měření v systémech managementu jakosti. Praha : Management Press, 2001. ISBN 80-7261-054-6. 